Article

\title{
Physico-Chemical Aspects and Complete Bacterial Community Composition Analysis of Wasp Nests
}

\author{
Chaolin Fang ${ }^{1}$ and Varenyam Achal ${ }^{1,2, *}$ \\ 1 Environmental Engineering Program, Guangdong Technion-Israel Institute of Technology, Shantou 515063, \\ China; chaolin.fang@gtiit.edu.cn \\ 2 Technion-Israel Institute of Technology, Technion City, Haifa 32000, Israel \\ * Correspondence: varenyam.achal@gtiit.edu.cn or varenyam@technion.ac.il
}

Received: 20 February 2020; Accepted: 19 March 2020; Published: 27 March 2020

check for updates

\begin{abstract}
Wasps are a group of social insects that build a house, known as a nest, from locally available building materials cemented by their saliva and secretions. Similar to termite nests, there could be many beneficiary bacteria present in their house that can play an important part in maintaining sustainability in soil ecosystems. Thus, the present study was initiated with a physico-chemical characterization of wasp nests collected from residential and forest zones, followed by unconfined compressive strength (UCS) and X-ray diffraction (XRD) analysis to identify major associated minerals. Further, MiSeq Illumina sequencing of the 16S rRNA gene (V3-V4 regions) was carried out to analyze complete bacterial community composition of wasp nests. The resulting data showed a dominance of Actinobacteria followed by Proteobacteria in both nests. Kaistobacter and Phycicoccus were the dominant genera in each type of wasp nest. It was concluded that wasp nests are an abundant source to isolate bacteria that can potentially be helpful in soil biogeochemical cycling and fertility, antibiotics production and bioremediation.
\end{abstract}

Keywords: bacterial diversity; biominerals; compressive strength; V3-V4 regions; wasp nest

\section{Introduction}

A home is a common need not only for human beings, but also for other animals such as birds and insects, which require shelter and protection from environmental calamities. Some members of the class Arthropoda including wasps, termites and ants (out of which many species are also known as 'social insects') make nests by depositing clay particles cemented by their salivary secretions. The terms mounds and hills are also used for such nests, although primarily for houses of termites and ants, respectively. Because of the ecological features of their houses not only providing strength but also contributing to soil fertility and nutrient cycling, wasps and termites are regarded as "ecosystem engineers" [1].

A wasp nest is similar to an anthill in possessing a concrete type material that cannot be easily broken. The detailed compositional analysis of wasp nests can be helpful in soil mechanics research or in ground improvement. It is known that biomineralization can play a role in soil strength [2]; however, it is too early to say if the strength of wasp nests comes from the same process and this warrants thorough study.

Further, bacteria isolated from nests of ecosystem engineers such as termites reportedly play an important role in antimicrobial production, biocontrol, bioremediation and bio-filtering [3-7]. Termite nests were shown to intensify crop growth due to their high nutrient content, and thus can be used as a biofertilizer [8,9]. Such nests have the potential of improving environmental sustainability [10]. Thus, it is worth evaluating such structures from microbiological points of view as well. There could 
be a possibility of specific bacteria playing a certain role in bringing strength to wasp nests; however, this is not yet verified.

Despite significant bacteria associated with nests of ecosystem engineers, there is limited information on this topic. The present study, therefore, first aims to characterize the physico-chemical properties of wasp nests, including their unconfined compressive strength. Vespula vulgaris is a common wasp, forming nests, found widely in temperate climatic regions of China. It is well understood that bacteria present in wasp nests will play a major role in maintaining the soil structure with ecological importance as wasps build nests using local building materials from the surrounding area. However, the complete bacterial community composition consisting of both the culturable and unculturable diversity of wasp nests is poorly understood. Thus, secondly, this study aimed to elucidate the bacterial community composition of wasp nests using Illumina Miseq sequencing of the V3-V4 regions of the 16S rRNA gene.

\section{Materials and Methods}

\subsection{Materials}

The first type of wasp nests used in this research was collected from an apartment located in the campus of Guangdong Technion Israel Institute of Technology, Shantou, Guangdong province of China, while another was collected from a small forest in a hilly area around this campus but about $100 \mathrm{~m}$ away from the residential zone, labeled as WH.1 and WH.2, respectively. The nests were collected in triplicates, three samples from each location. These wasp nests were built by the common wasp, Vespula vulgaris, with characteristic features of bright yellow and black bands along the body, and a visible waist between the thorax and abdomen. It should be noted that the temperate climate of this city makes it a suitable habitat for wasps.

\subsection{Physico-Chemical Analyses}

The physico-chemical characteristics including $\mathrm{pH}$, moisture, oxides composition and loss on ignition and unconfined compressive strength (UCS) of the wasp nests were calculated as per standard protocol. The unconfined compressive strength was measured in a UCS apparatus at an axial strain rate of $1 \% / \mathrm{min}$. In order to detect the chemical compositions of the wasp nests, samples were analyzed by X-ray fluorescence (XRF). The harvested wasp nests were pulverized into fine powder and then passed through a $2 \mathrm{~mm}$ sieve prior to any analysis.

\subsection{XRD Analysis}

In order to identify the crystal structures and mineral phases in wasp nests, which give them peculiar strength or structural characteristics, the samples from the raw wasp nests were determined using a Bruker D8 Advance X-ray diffractometer. A Cu- $\mathrm{k} \alpha$ radiation was used to generate diffraction patterns in the scanning angle $2 \theta$ at $10-80^{\circ} \mathrm{C}$.

\subsection{DNA Extraction, Amplicon Sequencing of $16 S$ rRNA Gene (V3-V4) and Data Analysis}

In order to elucidate bacterial diversity associated with wasp nests, the total wasp nest DNA was extracted using the DNeasy PowerSoil Kit (Qiagen, USA). The sampling process was carried out manually but in strict conditions to avoid any cross contamination. The outside materials from nests were removed and only inside materials were used for DNA extraction. The V3 and V4 regions of the bacterial 16S rRNA gene were amplified from isolated DNA using primers containing Illumina adapters [11]. For sequencing, Illumina Miseq was carried out by the Beijing Genomics Institute (BGI, Shenzhen). 
Following quality control, Usearch was used to cluster the sequencing data into operational taxonomic units (OTUs) at the $97 \%$ similarity level [12]. OTUs representing $1 \%$ or more of the total read relative abundance were used to obtain communities information of different classification level. The amplicon sequence data and metadata have been deposited in the NCBI Sequence Read Archive database under BioProject Accession Number PRJNA574000, submission ID SUB6342667.

\section{Results}

\subsection{Physico-Chemical Properties and Unconfined Compressive Strength (UCS) of the Wasp Nests}

The wasp nest soils were of clay texture with $\mathrm{pH} 6.35$ and 6.56 for WH.1 and WH.2, respectively. It is noteworthy that some components of the wasp nest material were similar to cement. The weight of all of the collected wasp nests was more or less the same, with an average weight of $112.8 \mathrm{~g}$ and a standard deviation of $1.4 \mathrm{~g}$. As depicted in Table 1, the wasp nest soils contained a high percentage of $\mathrm{SiO}_{2}$ and $\mathrm{Al}_{2} \mathrm{O}_{3}$. The UCS data obtained from WH.1 and WH.2 were 596 and $613 \mathrm{kPa}$, respectively.

Table 1. Percentage oxide composition in wasp nest soil.

\begin{tabular}{ccc}
\hline Parameters & WH.1 (\%) & WH.2 (\%) \\
\hline pH & 6.35 & 6.56 \\
Moisture & 17.2 & 16.6 \\
Silicon dioxide $\left(\mathrm{SiO}_{2}\right)$ & 61.28 & 61.64 \\
Aluminum oxide $\left(\mathrm{Al}_{2} \mathrm{O}_{3}\right)$ & 12.73 & 13.36 \\
Ferric oxide $\left(\mathrm{Fe}_{2} \mathrm{O}_{3}\right)$ & 5.57 & 5.28 \\
Calcium oxide $(\mathrm{CaO})$ & 1.28 & 1.65 \\
Magnesium oxide $(\mathrm{MgO})$ & 0.52 & 0.47 \\
Titanium oxide $(\mathrm{TiO})$ & 1.04 & 0.94 \\
Loss on ignition $(\mathrm{LOI})$ & 6.25 & 5.87 \\
\hline
\end{tabular}

\subsection{XRD Analysis of the Wasp Nests}

X-ray diffraction (XRD) showed the major minerals contained in wasp nest soil as confirmed by the various peaks against corresponding to 2 Theta Braggs angle (Figure 1). There were no significant differences in both WH.1 and WH.2 samples, where quartz remained the major mineral. This result is in agreement with the data obtained from physico-chemical properties of wasp nests. There were other minerals including carbonated ones and dickite in the samples.

\subsection{Amplicon Sequencing of $16 S$ rRNA Gene (V3-V4)}

The application of next-Generation DNA sequencing technologies provides information on bacterial diversity associated with any environment, including nests of ecosystem engineers [13]. Thus, the present study generated such information by amplifying the V3 and V4 regions of the bacterial 16S rRNA gene using Illumina Miseq sequencing. The result of the diversity index analysis based on OTU are provided in Table 2.

Table 2. Bacterial diversity index statistics of both wasp nests of the present study.

\begin{tabular}{ccccccc}
\hline Sample & $\mathbf{S}_{\text {obs }}$ & Chao1 & Ace & Shannon & Simpson & Coverage \\
\hline WH.1 & 1740 & 1783.413 & 1814.977 & 5.976614 & 0.007203 & 0.996318 \\
WH.2 & 1900 & 1911.982 & 1928.276 & 6.149132 & 0.006322 & 0.99832 \\
\hline
\end{tabular}




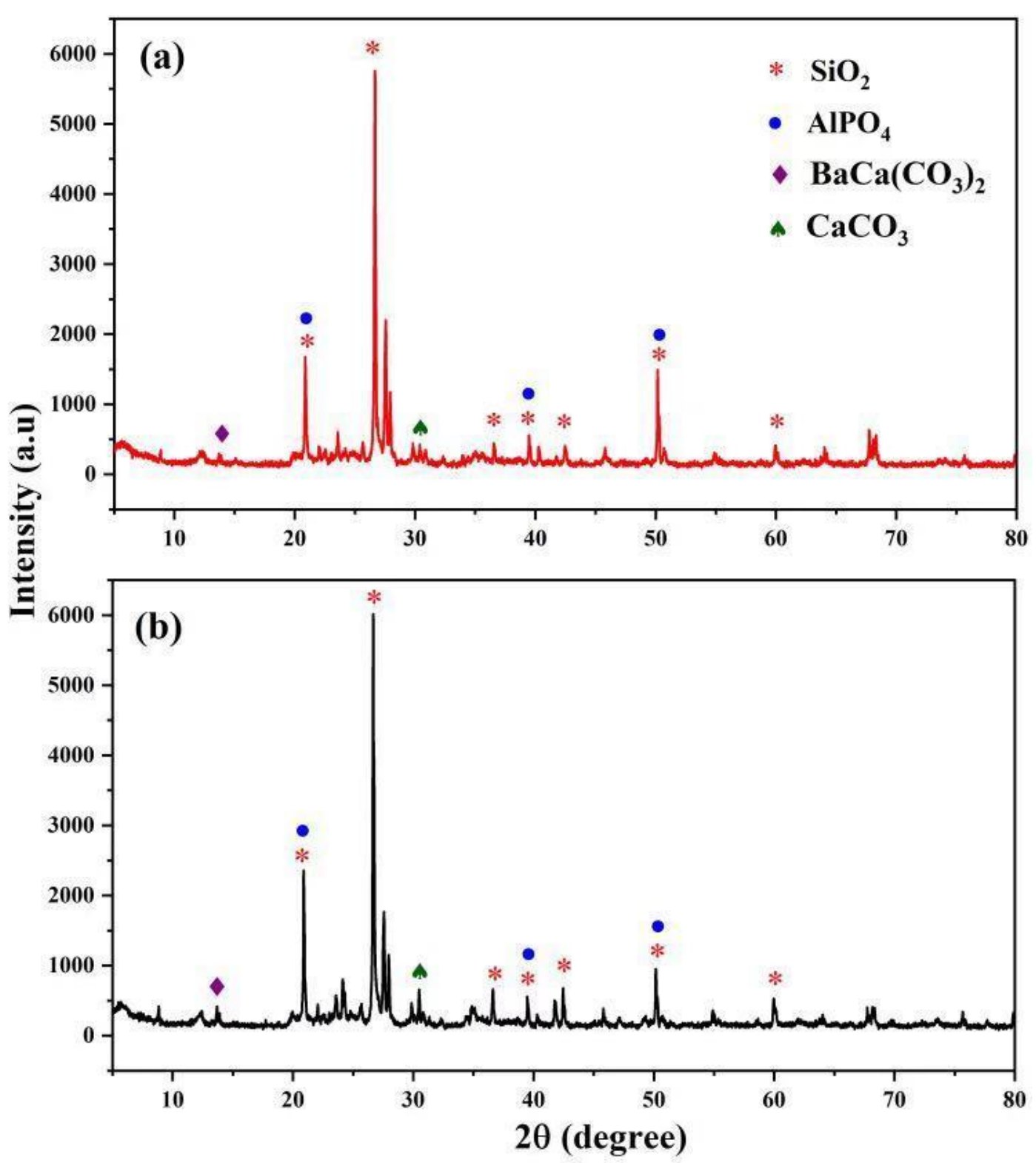

Figure 1. X-ray diffraction pattern of both wasp nests (a) WH.1 and (b) WH.2.

The similar coverage index in both WH.1 and WH.2 suggested the accuracy of this analysis. Sobs denoted the number of observed species in the wasp nests. The values obtained from Chao1 represented the community richness and estimated the total number of microbes, while the Shannon and Simpson indices represented the community diversity found in the wasp nests. The Sobs, Chao1 and Shannon indices of WH.1 were less than those of WH.2, suggesting a higher bacterial diversity associated with the $V$. vulgaris nest located in a natural environment of a small forest area. The number of OTUs corresponding to relative bacterial abundances is presented in Figure 2 and is in agreement with data obtained under Table 2. 


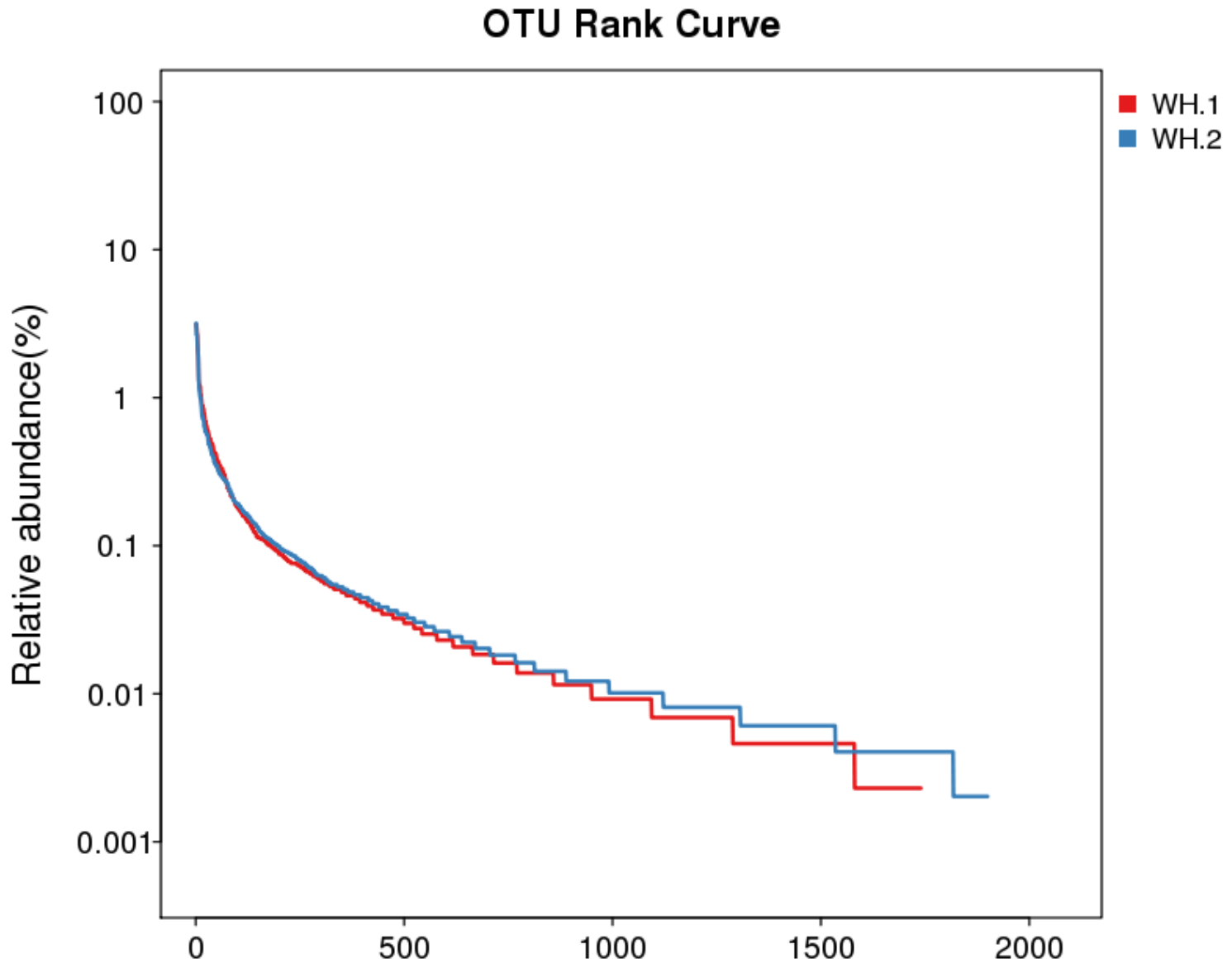

\section{Number of OTUs}

Figure 2. OTU rank curve for wasp nest samples.

\subsection{Bacterial Diversity Associated with the Wasp Nests}

The overall distribution of phyla showing predominance of bacterial OTUs belonging to Actinobacteria followed by Proteobacteria in the wasp nests is shown in Figure 3. Though Actinobacteria and Proteobacteria dominated in both WH.1 and WH.2, the latter showed a relatively greater bacterial diversity for those phyla. This variation could be due to different habitats (WH.1 was located in an apartment in a residential campus, while WH.2 in a small forest far from the residential area). The ecological environment of the forest area can be helpful in providing higher bacterial diversity.
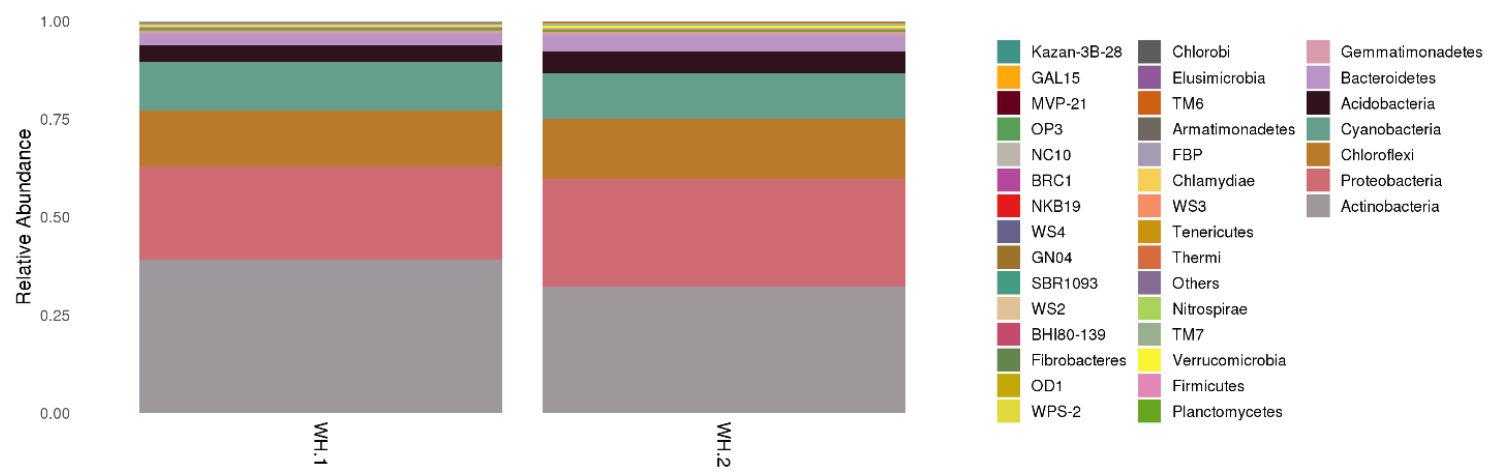

Figure 3. Phylum level distribution of bacterial community distribution in both wasp nests. 
In order to understand and find out if any differences existed between WH.1 and WH.2, the heatmap of bacterial abundance at class level is displayed in Figure 4. It shows a similar trend in terms of bacterial diversity, where the abundant classes were of Actinobacteria and Alphaproteobacteria, followed by Chloroflexi, Thermoleophilia and Anaerolineae. Kaistobacter, Phycicoccus, Arthrobacter, Micromonospora, Actinomycetospora, Pseudonocardia, Nocardioides, Methylobacterium and Leptolyngbya were major genera present in the wasp nests (Figure 5).

\section{Relative Abundance}
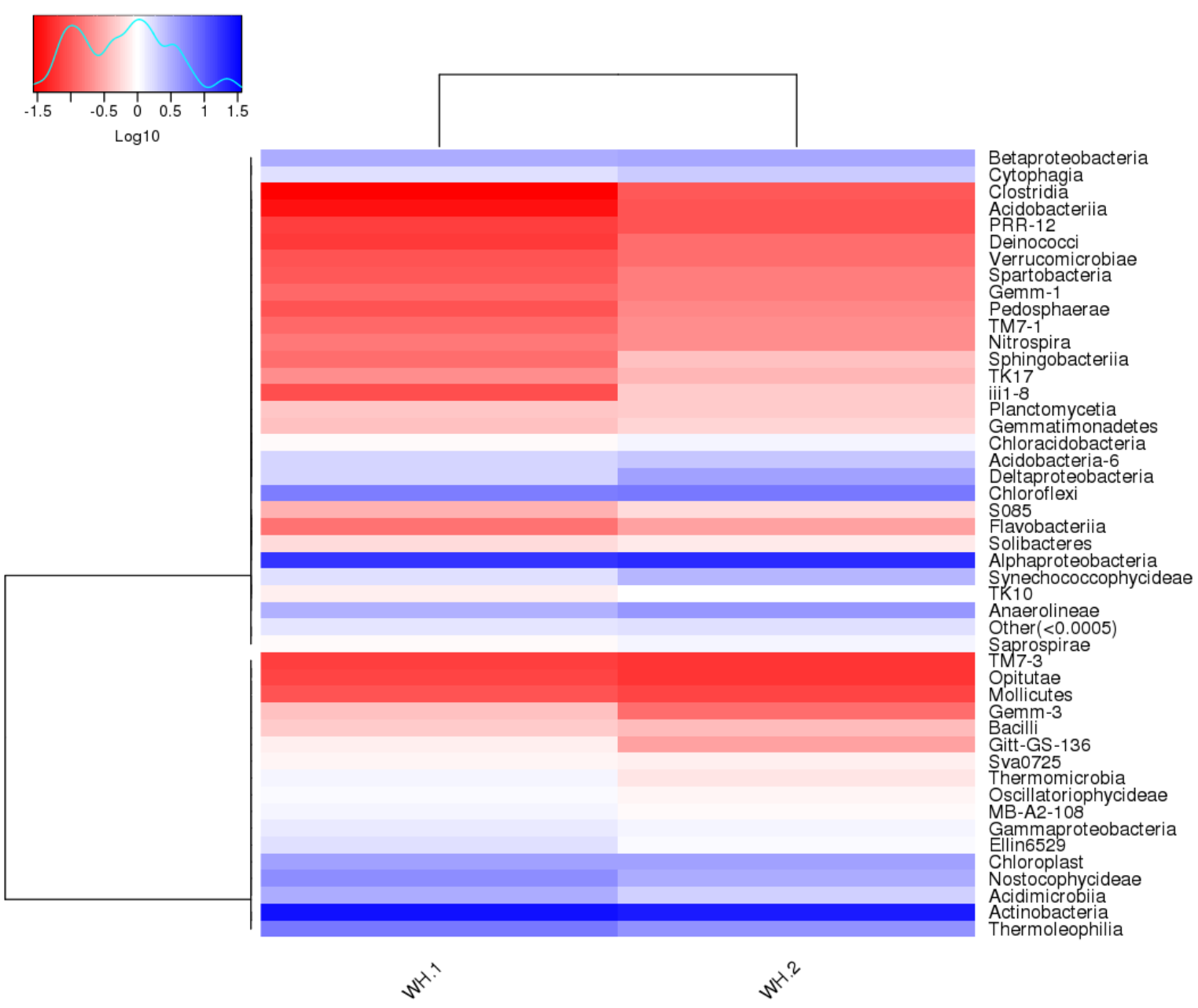

Figure 4. The bacteria class heatmap of the community structure in in both wasp nests. 

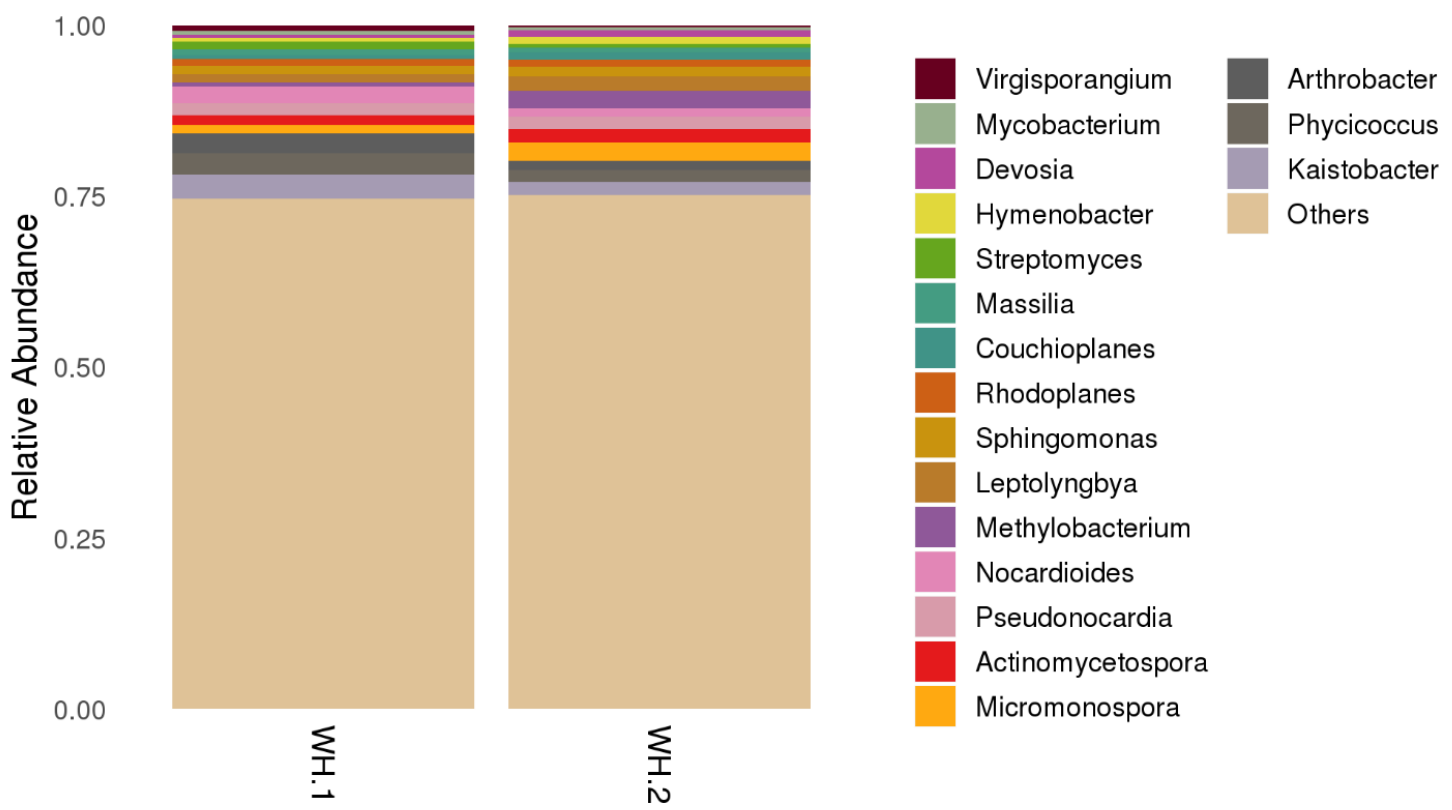

Figure 5. The bacterial genus community distribution in both wasp nests.

\section{Discussion}

The chemical properties, especially the amount of $\mathrm{SiO}_{2}, \mathrm{Al}_{2} \mathrm{O}_{3}$ and $\mathrm{Fe}_{2} \mathrm{O}_{3}$, and the $\mathrm{LOI}$ of the soil analyzed from wasp nests suggested that they are a suitable building material with pozzolans characteristics with properties of a class N pozzolan conforming to ASTM C618-03 by American Society for Testing and Materials [14]. If the sum of $\mathrm{SiO}_{2}, \mathrm{Al}_{2} \mathrm{O}_{3}$ and $\mathrm{Fe}_{2} \mathrm{O}_{3}$ makes at least $70 \%$, such a building material fulfills the requirement for natural pozzolans. The nature of wasp nests as a pozzolanic material could be one of reasons for their high unconfined compressive strength. Because of the high strength of other nests of such ecosystem engineers, including termite mounds, they are being used as an additive in construction [15]. The pozzolanic characteristics of wasp nest soil also classify it to be a secondary cementitious material.

The data from XRD indicated quartz as a major compound of wasp nests. Just like termite nests, wasp nests are also a source of quartz observed by other researchers [16]. The presence of carbonate minerals in the form of calcite and barytocalcite $\left(\mathrm{BaCa}\left(\mathrm{CO}_{3}\right)_{2}\right)$ further confirmed biomineralization activity in the wasp nests. As some insects are known to make carbonate minerals by biomineralization [17], it is possible that wasps will biomineralize carbonate as a cementing agent. Termites were shown to biomineralize calcium carbonate internally for building aboveground galleries [18]. The diverse bacterial diversity discussed in the next section could also play a role in carrying out biomineralization. The presence of calcite induced by bacteria is known to strengthen in building materials, including soil and sand [2]. The XRD spectra of the wasp nests provided evidence for the biomineralization hypothesis. Although the present study did not focus on a deeper understanding of biomineralization by $V$. vulgaris or in wasp nests in general, we believe the strength of nature's nest warrants further and more detailed studies.

Illumina Miseq sequencing of the V3-V4 regions of the $16 \mathrm{~S}$ rRNA gene of both the wasp nests revealed the predominance of bacterial OTUs belonging to Actinobacteria followed by Proteobacteria. Although there is no report on bacterial diversity from wasp nests, termite nests were reported to be an abundant and dominant source of Actinobacteria in other studies [4]. However, Acidobacteria and Firmicutes were reportedly dominant phyla in termite nests [13,19], differing from the findings of our study. Actinobacteria and Proteobacteria are known to play a role in comprising a substantial proportion of soil environments $[13,20,21]$. Actinobacteria can protect wasps from soil entomopathogens by producing secondary metabolites [22]. Chloroflexi, Cyanobacteria, Acidobacteria, Bacteroidetes and 
Verrucomicrobia were other predominant phyla in both wasp nests' soil. Occurrence of such phyla was also reported in other studies in termite nests $[8,13,19]$.

Many members of bacterial classes indicated in the heat-map were isolated from termite nest, which were identified as nitrogen fixers containing nifH genes $[13,19]$. This shows the potential of wasp nest soil to be used as a soil amendment for better crop growth [23].

Among major genera present in wasp nests, Kaistobacter was identified as the most prominent genus that could, being known as a disease suppression bacterium, play a role in providing protection to wasps from soil pathogens [24]. Arthrobacter and Micromonospora are generally known to be associated with the hindgut of insects, and play a role in cellulose decomposition [25]. Nitrogen fixing bacteria including Cyanobacteria (Leptolyngbya, as the genus under this phylum) have also been isolated from termite nests, and play an important role in nitrogen fixation [26].

Antibiotic-producing actinomycetes from Actinobacteria such as Pseudonocardia, Nocardioides and Actinomycetospora protect the host and their resources under insect-bacterial symbioses [27,28]. The cuticular microbiome of attine ants and fire ant workers were found to be dominated by Pseudonocardia and Nocardia spp. in other reports [29,30]. Pseudonocardia was isolated from termite nests in a previous study [31], and was also the dominant genus in subterranean nests [4]. The presence of Methylobacterium in wasp nests was not surprising, as nests of social insects are a known source for methanotrophs playing a certain role in methane oxidation [32].

\section{Conclusions}

This is one of first studies that analyzed a complete profiling of wasp nests and their associated bacterial diversity using the amplicon sequencing approach. The research concludes with wasp nests as an excellent microbial source to isolate bacteria for the purposes of bringing environmental sustainability with a defined role in the pharmaceutical and agricultural fields, in addition to bioremediation. Overall, the bacteria identified in wasp nests could carry out nitrogen fixation, bioremediation and methane oxidation; thus, they can play a sustainable role in the soil ecosystem. Wasp nest soil can be used as an additive for stronger building materials in soil mechanics and construction engineering as a supplementary cementitious material.

Author Contributions: Conceptualization, V.A.; methodology, V.A.; investigation, C.F.; data curation, C.F.; writing - original draft preparation, C.F.; writing - review and editing, V.A.; funding acquisition, V.A. All authors have read and agree to the published version of the manuscript.

Funding: This research was funded by the National Natural Science Foundation of China under grant number 41950410576.

Acknowledgments: The authors acknowledge the residents of Apartments B of Guangdong Technion, especially Dr. Nan Wang for helping in the sample collection.

Conflicts of Interest: The authors declare no conflict of interest.

\section{References}

1. Deke, A.L.; Adugna, W.T.; Fite, A.T. Soil physic-chemical properties in termite mounds and adjacent control soil in Miyo and Yabello districts of Borana zone, southern Ethiopia. Am. J. Agric. For. 2016, 4, 69-74.

2. Li, M.; Fu, Q.-L.; Zhang, Q.; Achal, V.; Kawasaki, S. Bio-grout based on microbially induced sand solidification by means of asparaginase activity. Sci. Rep. 2015, 5, 16128. [CrossRef] [PubMed]

3. Duponnois, R.; Kisa, M.; Assigbetse, K.; Prin, Y.; Thioulouse, J.; Issartel, M.; Moulin, P.; Lepage, M. Fluorescent pseudomonads occurring in Macrotermes subhyalinus mound structures decrease $\mathrm{Cd}$ toxicity and improve its accumulation in sorghum plants. Sci. Total Environ. 2006, 370, 391-400. [CrossRef] [PubMed]

4. Sujada, N.; Sungthong, R.; Lumyong, S. Termite nests as an abundant source of cultivable actinobacteria for biotechnological purposes. Microbes Environ. 2014, 29, 211-219. [CrossRef] [PubMed]

5. Krishanti, N.P.R.A.; Zulfina, D.; Wikantyoso, B.; Zulfitri, A.; Yusuf, S. Antimicrobial production by an actinomycetes isolated from the termite nest. J. Trop. Life Sci. 2018, 8, 279-288. 
6. Nauer, P.A.; Hutley, L.B.; Arndt, S.K. Termite mounds mitigate half of termite methane emissions. Proc. Natl. Acad. Sci. USA 2018, 115, 13306-13311. [CrossRef]

7. Enagbonma, B.J.; Babalola, O.O. Potentials of termite mound soil bacteria in ecosystem engineering for sustainable agriculture. Ann. Microbiol. 2019, 69, 211-219. [CrossRef]

8. Fall, S.; Nazaret, S.; Chotte, J.L.; Brauman, A. Bacterial density and community structure associated with aggregate size fractions of soil feeding termite mounds. Microb. Ecol. 2004, 28, 191-199. [CrossRef]

9. Watson, J.P. The use of mounds of the termite Macrotermes falciger (Gerstacker) as a soil amendment. J. Soil Sci. 1977, 28, 664-672. [CrossRef]

10. Enagbonma, B.J.; Babalola, O.O. Environmental sustainability: A review of termite mound soil material and its bacteria. Sustainability 2019, 11, 3847. [CrossRef]

11. Fang, C.; Achal, V. Biostimulation of calcite precipitation process by bacterial community in improving cement stabilized rammed earth as sustainable material. Appl. Microbiol. Biotechnol. 2019, 103, 7719-7727. [CrossRef] [PubMed]

12. Edgar, R.C. Search and clustering orders of magnitude faster than BLAST. Bioinformatics 2010, 26, 2460-2461. [CrossRef] [PubMed]

13. Manjula, A.; Pushpanathan, M.; Sathyavathi, S.; Gunasekaran, P.; Rajendhran, J. Comparative analysis of microbial diversity in termite gut and termite nest using ion sequencing. Curr. Microbiol. 2016, 72, 267-275. [CrossRef] [PubMed]

14. ASTM C618. Standard Specification for Coal Fly Ash and Raw or Calcined Natural Pozzolan for Use in Concrete; ASTM International: West Conshohocken, PA, USA, 2012.

15. Omofunmi, O.E.; Oladipo, O.I. Assessment of termite mound additive on soil physical characteristics. Agric. Eng. Int. CIGR J. 2018, 20, 40-46.

16. Ganguli, A.K.; Kumar, S.; Baruah, A.; Vaidya, S. Nanocrystalline silica from termite mounds. Curr. Sci. 2014, 106, 83-88.

17. Lowenstam, H.A.; Weiner, S. On Biomineralization; Oxford University Press: New York, NY, USA, 1989.

18. Liu, X.; Monger, H.C.; Whitford, W.G. Calcium carbonate in termite galleries-Biomineralization or upward transport? Biogeochemistry 2007, 82, 241-250. [CrossRef]

19. Makonde, H.M.; Mwirichia, R.; Osiemo, Z.; Boga, H.I.; Klenk, H.P. 454 Pyrosequencing-based assessment of bacterial diversity and community structure in termite guts, mounds and surrounding soils. SpringerPlus 2015, 4, 1-11. [CrossRef] [PubMed]

20. Schmitt-Wagner, D.; Friedrich, M.; Wagner, B.; Brune, A. Axial dynamics, stability, and interspecies similarity of bacterial community structure in the highly compartmentalized gut of soilfeeding termites (Cubitermes spp). Appl. Environ. Microbiol. 2003, 69, 6018-6024. [CrossRef]

21. Nakajima, H.; Hongoh, Y.; Noda, S.; Yoshida, Y.; Usami, R.; Kudo, T.; Ohkuma, M. Phylogenetic and morphological diversity of Bacteroidales members associated with the gut wall of termites. Biosci. Biotechnol. Biochem. 2006, 70, 211-218. [CrossRef]

22. Chouvenc, J.; Yaosu, N.; Robert, A. Inhibition of the fungal pathogen, Metarhizium anisopliae in the alimentary tracts, of five termite species. Fla. Entomol. 2010, 93, 467-469. [CrossRef]

23. Garba, M.; Cornelis, W.M.; Steppe, K. Effect of termite mound material on the physical properties of sandy soil and on the growth characteristics of tomato (Solanum lycopersicum L.) in semi-arid Niger. Plant Soil 2011, 338, 451-466. [CrossRef]

24. Liu, X.; Zhang, S.; Jiang, Q.; Bai, Y.; Shen, G.; Li, S.; Ding, W. Using community analysis to explore bacterial indicators for disease suppression of tobacco bacterial wilt. Sci. Rep. 2016, 6, 36773. [CrossRef] [PubMed]

25. Thayer, D.W. Facultative wood-digesting bacteria from the hind-gut of the termite Reticulitermes hesperus. J. Gen. Microbiol. 1976, 95, 287-296. [CrossRef] [PubMed]

26. Zehr, J.P.; Jenkins, B.D.; Short, S.M.; Steward, G.F. Nitrogenase gene diversity and microbial community structure: A cross-system comparison. Environ. Microbiol. 2003, 5, 539-554. [CrossRef]

27. Moran, N. Symbiosis. Curr. Biol. 2006, 16, R866-R871. [CrossRef] [PubMed]

28. Seipke, R.F.; Kaltenpoth, M.; Hutchings, M.I. Streptomyces as symbionts: A emerging and widespread theme? FEMS Microbiol. Rev. 2012, 36, 862-876. [CrossRef]

29. Sen, R.; Ishak, H.D.; Estrada, E.; Dowd, S.E.; Hong, E.; Mueller, U.G. Generalized antifungal activity and 454-screening of Pseudonocardia and Amycolatopsis bacteria in nests of fungus-growing ants. Proc. Natl. Acad. Sci. USA 2009, 106, 17805-17810. [CrossRef] 
30. Ishak, H.D.; Plowes, R.; Sen, R.; Kellner, K.; Meyer, E.; Estrada, D.A.; Dowd, S.E.; Mueller, U.G. Bacterial diversity in Solenopsis invicta and Solenopsis geminata ant colonies characterized by $16 \mathrm{~S}$ amplicon 454 pyrosequencing. Microb. Ecol. 2011,61,821-831. [CrossRef]

31. Sujarit, K.; Sujada, N.; Kudo, T.; Ohkuma, M.; Pathom-Aree, W.; Lumyong, S. Pseudonocardia thailandensis sp. nov., an actinomycete isolated from a subterranean termite nest. Int. J. Syst. Evol. Microbiol. 2017, 67, 2773-2778. [CrossRef]

32. Cappelletti, M.; Ghezzi, D.; Zannoni, D.; Capaccioni, B.; Fedi, S. Diversity of methane-oxidizing bacteria in soils from "Hot Lands of Medolla" (Italy) featured by anomalous high-temperatures and biogenic $\mathrm{CO}_{2}$ emission. Microbes Environ. 2016, 31, 369-377. [CrossRef]

(C) 2020 by the authors. Licensee MDPI, Basel, Switzerland. This article is an open access article distributed under the terms and conditions of the Creative Commons Attribution (CC BY) license (http://creativecommons.org/licenses/by/4.0/). 